\title{
Is there a Sheriff anymore? Vietnam's legacy on US-Nicaraguan relations during the Carter Era, 1977-1981
}

\author{
Ivan McLaughlin
}

School of History, UCC

\begin{abstract}
For too many years, we've been willing to adopt the flawed and erroneous principles and tactics of our adversaries, sometimes abandoning our own values for theirs. We've fought fire with fire, never thinking that fire is better quenched with water. This approach failed, with Vietnam the best example of its intellectual and moral poverty. But through failure we have now found our way back to our own principles and values, and we have regained our lost confidence. Jimmy Carter, May 22, 1977, Notre Dame University.
\end{abstract}

My project explores the extent to which the Vietnam legacy influenced US-Nicaraguan relations during the transition of power that took place in Nicaragua during James Earl Carter's presidency. The Vietnam legacy is characterised by the increased influences of the US Congress, press, public and Latin America on US executive decisions. Understanding the role of the Vietnam legacy shows that the Carter administration had not regained the US's 'lost confidence.' The US's anxiety over Vietnam remained and left a void in the Western Hemisphere when Nicaragua needed guidance and assistance from the US during its political transition.

\section{Nicaragua: a landscape of revolution}

On July 19, 1979, the forty-year old traditionally US backed dictatorship led by Anastasio Somoza Debayle was overthrown in Nicaragua by a coalition of Nicaraguans encompassing the business, academic, religious and working classes. Somoza's opponents went on to create a new government for Nicaragua. Although they were initially euphoric in the aftermath of Somoza's ouster, it did not take long for underlying political and economic differences to fragment Nicaragua's new government. This was exacerbated by their inheritance of a country on the brink of bankruptcy and heavily burdened by the need to reconstruct Nicaragua's infrastructure in the aftermath of the civil war.

The political transition that took place in Nicaragua was heavily influenced by the foreign policy pursued by the US government headed by President Jimmy Carter. By researching newly declassified US government documents it is possible to trace the executive's increased acknowledgment of the powerful role of the US Congress and the domestic press 
in influencing executive decision making towards revolutionary events in Nicaragua. The Carter administration was trying to decrease its role as leader to the continent, promoting a policy of non-intervention to encourage Latin American countries to determine their own destinies. Countries such as Venezuela and Panama played a major role in influencing events in Nicaragua by aiding opposition to Somoza, while both the Somoza regime and the Sandinista-led opposition attempted to manipulate the US government's anxiety over its traditional role as Sheriff. During the Carter administration, thus, Nicaragua was a key symbol of the US government's acknowledgement of its declining role as guide to democracy in Central America. Although no particular Latin American country would become the key leader of the hemisphere, countries like Venezuela and Panama began to act on their own accord to influence the hemisphere and not necessarily follow the United States.

On July 20, 1979, a new coalition government predominantly led by the Sandinista National Liberation Front (or the Sandinistas) took over from Somoza in Nicaragua. The Carter administration saw the Sandinistas as Marxist and was increasingly fearful of revolution and the ideology of Communism spreading across the rest of Central America. In another Central American country, El Salvador, the civil-military Revolutionary Government Junta deposed Salvadoran President Carlos Humberto Romero on October 15, 1979, only a few months after the Somoza regime collapsed in Nicaragua. Cuba's increased influence in Nicaragua, through its provision of teachers, doctors and military training to Nicaragua, was interpreted by the United States as Cuba and the Soviet Union attempting to spread revolution in Latin America. In response, the Carter administration pursued a policy emphasising the provision of economic aid for reconstruction as a means of containing the possibility of Central America looking towards Cuba as its revolutionary guide due to its own revolution in 1959. The Carter administration also hoped that economic assistance would prevent any possibility of the region looking towards the Soviet Union as the key influence on its society. Carter and his administration in effect were combining the two contexts of the Vietnam legacy and the Cold War to create a new style US policy.

The Carter administration found it difficult to release the economic assistance required for Nicaragua. The Central Intelligence Agency (CIA) felt such economic assistance would be diverted by the Sandinistas to spread revolution across Central America. Consequently, the CIA continued to hold up the economic assistance by presenting its findings to Congress of alleged Cuban/Soviet activities in the region. In the midst of US assistance being delayed, the Nicaraguan government began to crack, with leading moderate figures leaving its main governing body. As a result the Sandinistas found themselves having to keep the country afloat and took a series of actions to uphold order such as postponing upcoming elections, putting restrictions on the press and arresting members of the business class that had been once central and influential to Nicaragua's new government. 


\section{The Vietnam legacy and its importance}

The Vietnam War is fundamental to understanding subsequent US foreign policy decisions. In its aftermath, the United States grew anxious of its role as leader and guide of the world. Individual memory by Vietnam veterans' accounts of the war contributed to the increased anxiety of the US's role in the world. The collective memory, furthermore, of US participation in the war created by the press and attempts by Congress since 1975 to influence executive decision making contributed to this anxiousness. The combination of public opinion against war and US foreign policy intervention since 1975 has been dubbed the 'Vietnam Syndrome.' The term was coined in the early 1980s by a right-wing conservative opposition led by Ronald Reagan. They protested the Carter administration's policies that promoted human rights and arms restrictions on the grounds that the US's global power was decreasing and the Soviet Union's was increasing. Past scholarship has illustrated that the memory of Vietnam and its legacy persuaded Carter to pursue a new US foreign policy based on the promotion of human rights as opposed to intervention in international affairs. However, although Nicaragua acted as a testing ground for Carter's human rights policy, the extent to which the Vietnam legacy influenced US policy towards Nicaragua during this period has not been explored by historians in detail.

The main influence on my study of the Vietnam legacy and US-Nicaraguan relations has been the work of other scholars in relation to the Vietnam legacy, memory and syndrome towards US foreign policy around the world. This scholarship has examined different elements of the war's legacy ranging from the Nixon to the recent Bush administration. Although these studies take in many countries, such as Iraq, a primary-source based study has yet to be produced that evaluates the impact of the Vietnam War's memory, legacy and syndrome on US policy towards Nicaragua.

\section{Library and archival research in the United States}

My project is primarily based on researching government and media sources in the United States. In December 2009 and September 2010 I conducted research at the Carter Presidential Library, Atlanta, Georgia, and obtained government documents declassified as recently as 2008 and 2009. At the core of these sources are high-level decision making on Nicaragua by key figures of the Carter administration, such as Secretary of State Cyrus Vance, National Security Advisor Zbigniew Brzezinski and President Jimmy Carter himself. In August 2010, I obtained valuable material on US-Nicaraguan relations from collections on the State Department, the Bureau of Inter-American Affairs and the Office of Central American Affairs at the National Archives, College Park, Maryland. In August 2010, I also achieved an insight into the Congressional influence on the Carter administration's policy on Nicaragua by obtaining copies of the Congressional Hearings from the Law Library of 
Congress, Washington, D.C. UCC's School of History travel grants scheme has provided invaluable funding and assistance to make such trips a possibility. The School of History also provides temporary loan of laptops for research trips and digital camera tripods.

I have been on a fellowship in Glucksman Ireland House, New York University since November 2010 and will be in New York until August 2011. This has allowed me to avail of important primary source material in relation to US-Nicaraguan relations. Through New York University's electronic resources and the Digital National Security Archive, I have researched US government documentation available at the National Security Archive, The George Washington University, Washington, D.C. I have also availed of New York University's holdings on newspapers like The New York Times, The Washington Post, the Christian Science Monitor, BBC Summary of World Broadcasts and translations of Central American and South American broadcasts by the Foreign Broadcast Information Service (FBIS). While based in New York, I have also been able to research English and Spanish language newspapers in the New York Public Library and the Howard-Tilton Memorial Library, Tulane University, New Orleans. Furthermore, I have been able to study Nicaraguan governmental material and personal papers of major Nicaraguan political figures at the Hoover Institution, Stanford University, California.

\section{The importance of newly declassified US government documents}

Recently declassified Carter Presidential Library material has provided an invaluable insight into the high-level decision making of the Carter administration, which has not been available to previous scholars on US-Nicaraguan relations. Much of the material in relation to Carter was produced from a contemporary perspective in the 1980s and 1990s, by authors such as Robert Pastor (1987). These works, thus, were unable to avail of these primary documents. Furthermore, more recent works on the topic by Morris H. Morley (2002), Mauricio Solaún (2005) and Pastor's second work on Nicaragua, published in 2002 , could not avail of primary source material declassified as recently as 2008. Morley, Solaún and Pastor drew primarily on oral interviews, newspapers, and the government documents they could source did not document high-level decision making. I will build on the important work by these authors, by producing a study that encompasses the newly declassified primary documentation on US-Nicaraguan relations, thereby evaluating the Carter administration at a pivotal changing point in the US's foreign relations. By understanding the fears and anxieties the Carter administration felt towards intervening in Nicaragua's revolutionary upheaval, comparisons can be made with subsequent US administrations. Above all, we could expand our understanding of the possible fears and anxieties felt by the Obama administration in creating its foreign policy towards countries currently experiencing revolution. 
I would like to thank my supervisor Professor David Ryan and all my colleagues in the School of History, University College Cork for their continuous help and advice. I would also like to thank Ruth Martin, Cambridge University, for reading previous drafts of this article. Many thanks also to the editors and article reviewers at the Boolean.

\section{References}

\section{Books of Interest}

Morley, Morris H., Washington, Somoza and the Sandinistas: State and Regime in U.S. Policy Toward Nicaragua, 1969 -1981 (New York: Cambridge University Press, 2002).

Pastor, Robert A., Condemned to Repetition: The United States and Nicaragua (New Jersey: Princeton University Press, 1987).

Pastor, Robert A., Not Condemned to Repetition: the United States and Nicaragua (Boulder: Westview Press, 2002).

Solaún, Mauricio, U.S. intervention and regime change in Nicaragua (Nebraska: University of Nebraska Press, 2005). 